\title{
BARN OWL NESTING IN MANITOBA
}

ROBERT W. NERO, Wildlife Branch, Box 24, 1495 St. James St., Winnipeg, MB. R3H OW9

Until 9 June 1994 I had never seen a Barn Owl in the wild but that evening I photographed a female incubating eight eggs. It was an exciting moment. Réal McCaughan led the way up a stepladder to a small hatch opening into the attic of his two-storied house. With his trouble-light we could see the bird crouched in one corner about 12 feet $(3.6 \mathrm{~m})$ away. Numerous dried vole carcasses were lying about on a layer of fluffy "cellufibre" insulation. At my suggestion, Réal crawled in until he was close to the bird, which until then hadn't moved. When he touched her with a short stick, the owl jumped up, revealing the eggs, hopped around agitatedly for a moment, then flew

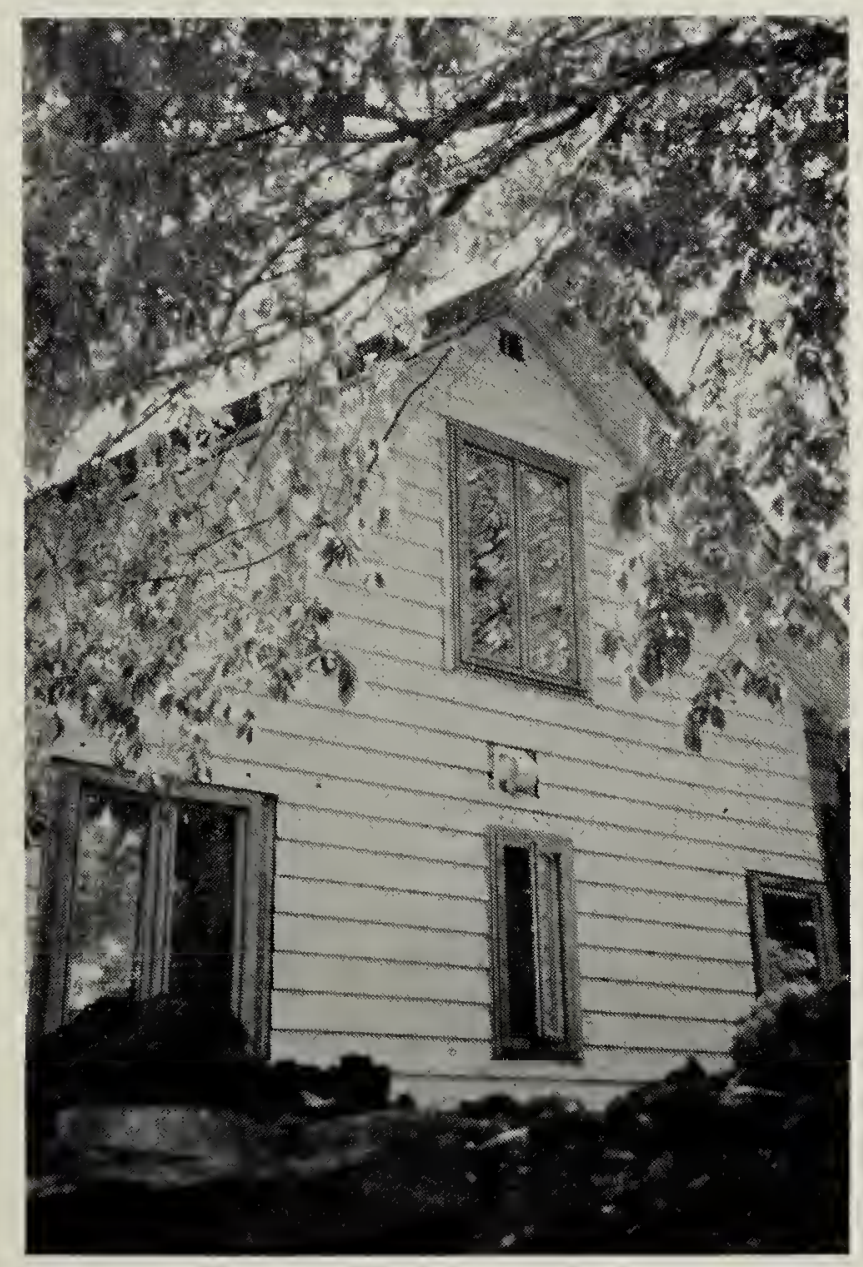

Nest site entrance

R. Nero out an opening into the night. We then withdrew. We had verified the first known nesting of this species for the Prairie Provinces.

A more unlikely nest site could hardly be imagined. It was in the attic of a house occupied by a family of seven persons in the hamlet of Springstein, about 6 miles $(10 \mathrm{~km})$ west of Winnipeg (Fig. 1-A). The birds had access to the attic through small openings about 22 feet $(6.7 \mathrm{~m})$ high at the north and south gable ends of the house. These openings, each about a foot $(30 \mathrm{~cm})$ square with a stud in the middle, were left when metal vents were removed during house renovations in fall 1993.

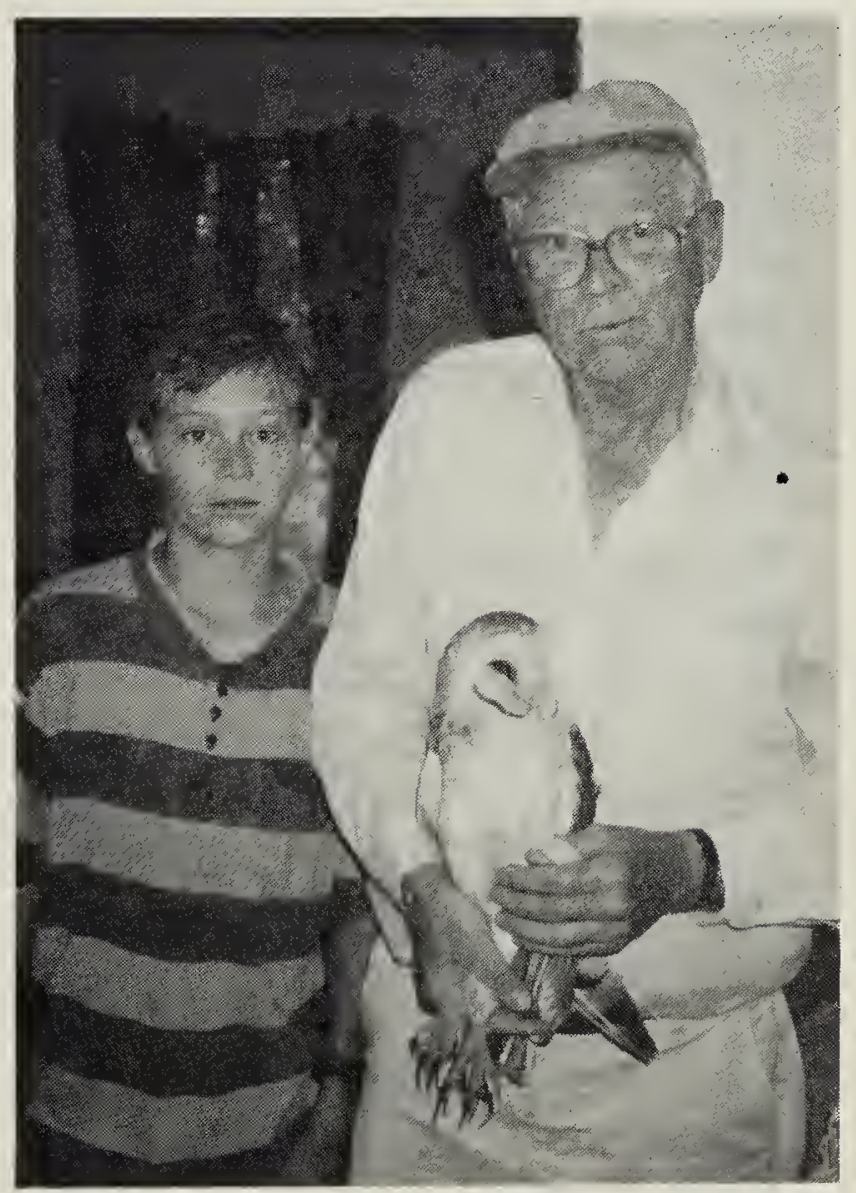

James and Jesse McCaughan and author with banded Barn Owl, 9 July 1994

McCaughan family photo 


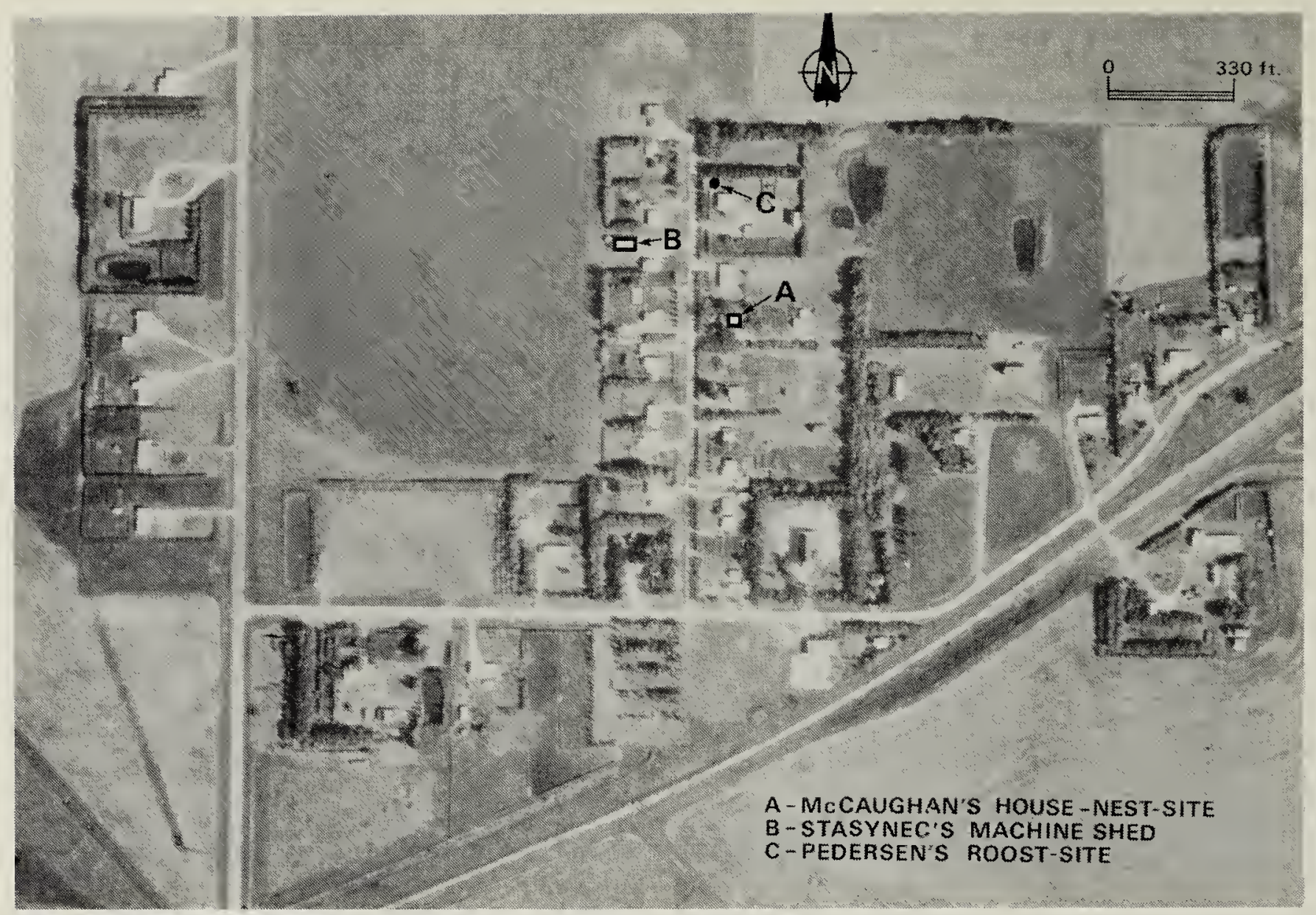

Figure 1. Location of nest sites.

The renovations had proceeded all winter and into summer. Constant hammering, use of a jackhammer, and on one day, even major excavation with a backhoe next to the north end of the house and adjacent to the nest site failed to deter the birds. The nest was close to the vent opening where a large elm stands nearby, providing convenient perches and cover.

Springstein is surrounded by open agricultural land, but the hamlet contains numerous trees, some grassy fields and several dugouts. One of the dugouts near the nest site has become a cattail marsh, attracting nesting Red-winged Blackbirds and other birds. Horse pastures, barns, sheds and houses make up the remainder of the habitat available to the owls.

Réal McCaughan, and his wife Kate, said that initially three "white owls" were seen, beginning on 19 April. Kate said the birds were noisy and conspicuous, even perching in the elm tree outside her window, from mid-April to the end of May. Their "screeching" calls were heard regularly after dark. A neighbour who lives two houses north, Ann Pedersen, later told me that in April she too had seen three "pale-coloured owls" flying over her yard. Upon checking her bird book, she decided that they were Barn Owls. She was apparently the first person to identify them.

One evening about 20 May, Réal saw two owls "fighting over the female," and then the bird presumed to be the female went into the attic opening. Egg-laying presumably began some time in late May when the owls suddenly settled down; they became quiet and inconspicuous and the McCaughans thought that the birds had moved away. A little later, however, James and Jesse McCaughan heard vocalizations from owls in the attic, so nesting was suspected. Connie Loeppky, who lives 
nearby, recalled that around 4 June, when there were several people partying outdoors in the evening, two owls circled and called overhead. She thought they might be Barn Owls. When she told a colleague of hers about the "Barn Owls," things got stirred up. Adolf Ens, a Winnipeg birder who had previously seen Barn Owls in British Columbia, came out one evening with two other birders. They attempted unsuccessfully to bring the birds into sight by playing taped Barn Owl calls. Late in the evening of 8 June, Ens saw two Barn Owls flying up over the trees and across the street; at 10:30 p.m. he saw another Barn Owl come out of the nest entrance. Following Dr. Ens' confirmation, Kate McCaughan phoned Natural Resources in order to establish "official notice" of the presence of these rare birds. And that's when I became involved.

The evening of 10 June Dennis Fast, who had been contacted earlier by Ens, visited the site with me and took two photos from the hatch opening of the owl on the nest. In order to avoid disturbing the birds any further, it was agreed that we would wait until the eggs had hatched before taking any other action. In addition, as requested by Réal McCaughan, the nest site locality was kept confidential. The location of the nest in a private home precluded making regular observations of the nest itself, so I undertook a search for additional information by talking to neighbours and looking for owl sign. Upon learning from James MlcCaughan in the evening of 16 June that he had seen a Barn Owl fly in and out of Garry Stasynec's large machine shed just down the street that afternoon, we hurried over for a look (Fig. 1-B). Garry came with us. We found whitewash on the floor just inside the large opening and at the back, along with several owl pellets, evidence of a roost site. Judy Stasynec recalled that an owl had been in the shed in early spring as well. An owl, probably the male, continued to roost in this shed occasionally through July (and perhaps later). One owl had been seen in the daytime by Ann Pedersen in May roosting in a spruce tree in their shelterbelt (Fig. 1-C); there we picked up several Barn Owl pellets, which conformed to the description provided by Mikkola: "black, characteristically shiny appearance and large size."13

Though I looked in several buildings, under trees and by fence posts throughout Springstein, I found few other pellets, and the male's main roost site remained undiscovered. I would have liked to explore further one decrepit old barn, but the owner, worried for my safety, was unwilling to let me climb into the loft. Somewhere, there must still be a large accumulation of pellets from the male owl (and perhaps an owl or two!). Since I was unable to thoroughly examine the entire area of McCaughan's attic, the male's main roost might even have been there. Voous notes: "Day-roost sites and nest sites are generally the same and the female at least tends to stay in her chosen nest site the whole year round. Whenever possible, male and female remain together for life and they sit close together by day." ${ }^{21}$

An owl, presumably the male, was seen occasionally at night by residents. Though mainly nocturnal, Barn Owls sometimes hunt during daylight hours. ${ }^{12,21}$ । spent several hours on a number of days searching for the male, but saw it only on 2 July. I stood beside McCaughan's house late that evening watching the entrance to the nest site. While I was talking to Réal at 11:00 p.m., the 
male landed momentarily on the top of a large spruce tree a few yards (metres) from the house. I barely had time to get my binoculars on it before it left. It looked silvery-white against the starlit sky.

Thinking that when the eggs hatched we could transfer the young to a nest box outside McCaughan's house, I built a box 4 feet $(1.2 \mathrm{~m})$ long and about 1.5 feet $(0.4 \mathrm{~m})$ square. On 28 June, with the help of Réal and his son Joe, we placed it 20 feet $(6.1 \mathrm{~m})$ up in the elm tree, about 25 feet $(7.6 \mathrm{~m})$ from the house. A layer of insulation, the same as in the attic, was then added to the nest box. That evening, I entered the attic at 9:00 p.m. to check on conditions. To my surprise, the female had moved her eggs about 4 feet $(1.2 \mathrm{~m})$, close to the entrance. She appeared more aggressive than on our previous encounter, holding her wings out and softly bill-snapping. I couldn't tell whether the sound was produced by the bill (bill-snapping) or by the tongue. According to several authorities, this sound is produced by the tongue, hence "tongue-clicking" is preferred by some. ${ }^{11,12,21}$ As I approached, she went into displacement behaviour, her head down, going through the motions of rolling eggs back under her body, while still covering the actual eggs. Then she raised up, faced down, and displayed her wings more fully, tongueclicking all the while. I judged from her behaviour that the eggs were close to hatching.

In the evening of 9 July, we checked the attic for the third and final time and found the female still on the nest. I had decided that if the eggs hadn't hatched by this date, they were not going to, and consequently we should attempt to capture the owl for banding. While I held the flashlight, McCaughan crawled into the attic with a small net l'd brought along. As he approached, the owl stood silently over the eggs, spreading her wings and swaying. Marti identifies this as a threat display. ${ }^{12}$ McCaughan then netted the bird and we brought her down to the landing. After we banded the bird, which was surprisingly quiet and passive, I went back and collected three of the seven eggs (one was missing), all of which were addled (i.e. they "sloshed" when shaken). Houston et al. suggest that "most if not all addled eggs represent embryo death." (Later, when I cleaned the three eggs, the contents, removed through small drilled holes, showed an apparent lack of development. They may have been infertile. Toxic ingredients in the insulation on which the eggs rested - cellu-fibre comes treated with some potent preservatives - also could have adversely affected the eggs.) I hurriedly gathered up 30 small pellets, eight vole carcasses and one deer mouse carcass; one vole was fresh. This took me about 10 minutes. We then released the owl back into the attic and withdrew. Barn Owls typically store excess prey at the nest site. As many as 189 prey items have been found at one site. ${ }^{12}$ Voous notes: "When incubating, the female leaves the nest for no more than 10-12 minutes at a time; she is fed by the male, who often stands guard close to her by day, and, in good years, he accumulates a large stock of prey at the nest site." ${ }^{21}$

A day or two after we banded the owl, Ann Pedersen's daughter saw an owl fly in the daytime from the direction of the nest site toward her house and across the street toward the machine shed. This was presumably the male, seen by Garry Stasynec flying out of the machine shed at 


\begin{tabular}{|c|c|c|}
\hline Particulars & Location & Date \\
\hline \multicolumn{3}{|l|}{ Manitoba } \\
\hline Specimen, shot & Ste. Anne & 6 November $1912^{15}$ \\
\hline Caught in barn & Sperling & ca. January $1925^{15}$ \\
\hline Specimen, shot, photo & Whitewater Lake & early October $1927^{1,15}$ \\
\hline Specimen, shot & La Riviere & 8 April $1945^{15}$ \\
\hline Sighting & Lac du Bonnet & ca. $1950^{20}$ \\
\hline Shot & Netley Marsh & 20 September $1960^{14,16}$ \\
\hline Sighting, in barn & Holland & ca. September $1985^{15}$ \\
\hline Sighting & Pilot Mound & November $1991^{15}$ \\
\hline \multicolumn{3}{|l|}{ Saskatchewan } \\
\hline Sighting, specimen, shot & Balcarres & 29 April/1 May $1910^{3}$ \\
\hline Specimen, shot & Aylesbury & 5 May $1924^{3}$ \\
\hline Carcass & Kindersley & 18 May $1960^{3}$ \\
\hline Sighting & Regina & 3 May $1966^{17}$ \\
\hline Sighting & Regina & 16 October $1987^{6}$ \\
\hline \multicolumn{3}{|l|}{ Alberta } \\
\hline Sighting, heard (2) & Elkwater & 22 July $1967^{18}$ \\
\hline Photo & Lethbridge & 8 July $1979^{4}$ \\
\hline
\end{tabular}

7:30 a.m. on 15 July. Garry also flushed the owl out of the shed at about midnight on 23 July. James McCaughan said he heard two owls in the attic, one of which flew out at 10:30 p.m. on 29 July. My impression is that the female continued incubating to at least mid-August. No further observations are available.

The Barn Owl has been listed since 1984 as vulnerable by the Committee on the Status of Wildlife in Canada (COSEWIC). Godfrey shows it breeding only in extreme southwestern British Columbia and southern Ontario, noting that it winters within its breeding range. ${ }^{4}$ Martin K. McNicholl points out that now "the Ontario population is probably extirpated" (pers. comm. October 1994). In the Prairie Provinces, the Barn Owl is considered a "casual wanderer." 4 Published records for that region are shown in Table 1. Nearly all records are of single birds.

The occurrence of breeding Barn Owls in Manitoba at all is surprising, their usual breeding range being much farther south. ${ }^{11}$ The northern distribution of this species appears to be limited by low temperatures. Low fat reserves, a slightly lower metabolic rate than for other owls, and feathers with a lesser insulative value are some reasons why Barn Owls are poorly adapted to cold climates; in the northern United States, many succumb to severe winter weather. ${ }^{8,12}$ In Minnesota, the species occurs casually in the southern half of the state, where it "was formerly more regular in occurrence." ${ }^{5}$ A 1990 nesting south of the Twin Cities was "the first in the state since 1963." Janssen noted (pers. comm. June 1994): "The DNR put up a nest box in 1991 \& they again nested that year but they have not been heard of since nor have we any records of occurrence in the state since that time." In North Dakota, the Barn Owl is considered "rare, irregular and local"; five records are given, 1915-1952, of which three are for the eastern third of the state, including a nest west of Fargo in 1952. ${ }^{19}$ A Barn Owl nest found in southern Montana in 1989 was the first for the state, the first record being a specimen found dead in $1950 .^{8}$ In Missouri, where the Barn Owl is considered endangered, 
captive-breeding is being used to supplement the wild population. ${ }^{7}$

Although the sample is small, the Barn Owl records for the Prairie Provinces (Table 1), plus the present 1994 record, curiously show an appearance of clumping. The years of occurrence seem to fall into four groups: 1910-27, 1945-60, 1960-79, 1985-94. This may be merely coincidental, or it may have some relationship to population changes farther south or other factors.

Barn Owls may have been attracted to the Springstein area in 1994 by an abundance of prey. That year, a high vole population was observed general!y throughout southern Manitoba. Some landowners I spoke to considered the numbers of voles unprecedented. Owing to an unusually wet season in 1993, numerous unharvested crops provided abundant food and cover for small mammals. Two yards north of the nest site, where flax straw covering a septic field didn't get cleaned up, there were many voles. I watched voles in Pedersen's yard trotting down a ramp from inside an active rabbit hutch and I saw others scrambling next to the concrete steps to the house. From pellets found at the nest site and elsewhere, I obtained crania and mandibles of 84 prey items. These were identified by Jim Duncan as follows: Meadow Vole, 76 individuals; and Deer Mouse, eight individuals. According to Marti, voles are the "dominant prey" of the Barn Owl in much of North America. ${ }^{12}$

The three Barn Owls may also have been part of a small resident population of owls in this area. As improbable as that seems, it may be worth considering. The Barn Owl is a highly nocturnal species, nesting and roosting in a variety of sites including even old machinery, under bridges, old water tanks, abandoned wells, etc. ${ }^{11,12,13,19}$ These are not places usually checked by birders. In June and July 1994, looking for signs of Barn Owls (and that elusive third one!), I looked in more than 30 deserted houses, barns, sheds, empty granaries, a silo, and under six bridges in the area west of Winnipeg. I didn't find any Barn Owls or their sign, but I found that searching this kind of habitat is dirty, dismal and dangerous (I stepped through the hayloft floorboards in one old barn), and often involves some strenuous climbing. I flushed a Great Horned Owl out of two buildings and found feathers of this species in two others; numerous pellets found nearby were probably from this species. Wayne C. Harris, who has "spent a lot of time searching old barns and buildings in search of owl pellets" in Saskatchewan, has found "a considerable number" of Great Horned Owls, but never a Barn Owl (pers. comm. August 1994). Great Horned Owls could be a factor limiting Barn Owl occurrence, for they are considered to be the Barn Owl's "main natural enemy in North America." 21

It appears that Barn Owl habitat in this area is plentiful, most of the available structures I checked being close to or surrounded by trees, grassy fields, dugouts and cropland. Cowan has shown that following an increase in numbers of derelict houses, barns, sheds, etc. in the northern Great Plains over the last several decades, the Raccoon, which shelters in such structures, expanded its range northwards. ${ }^{2}$ Perhaps the same abandoned structures have provided shelters for the Barn Owl. Records of this species in Manitoba go back some 80 years. That seems a long time for a species to occur in an area solely on the basis of casual wandering. We now 


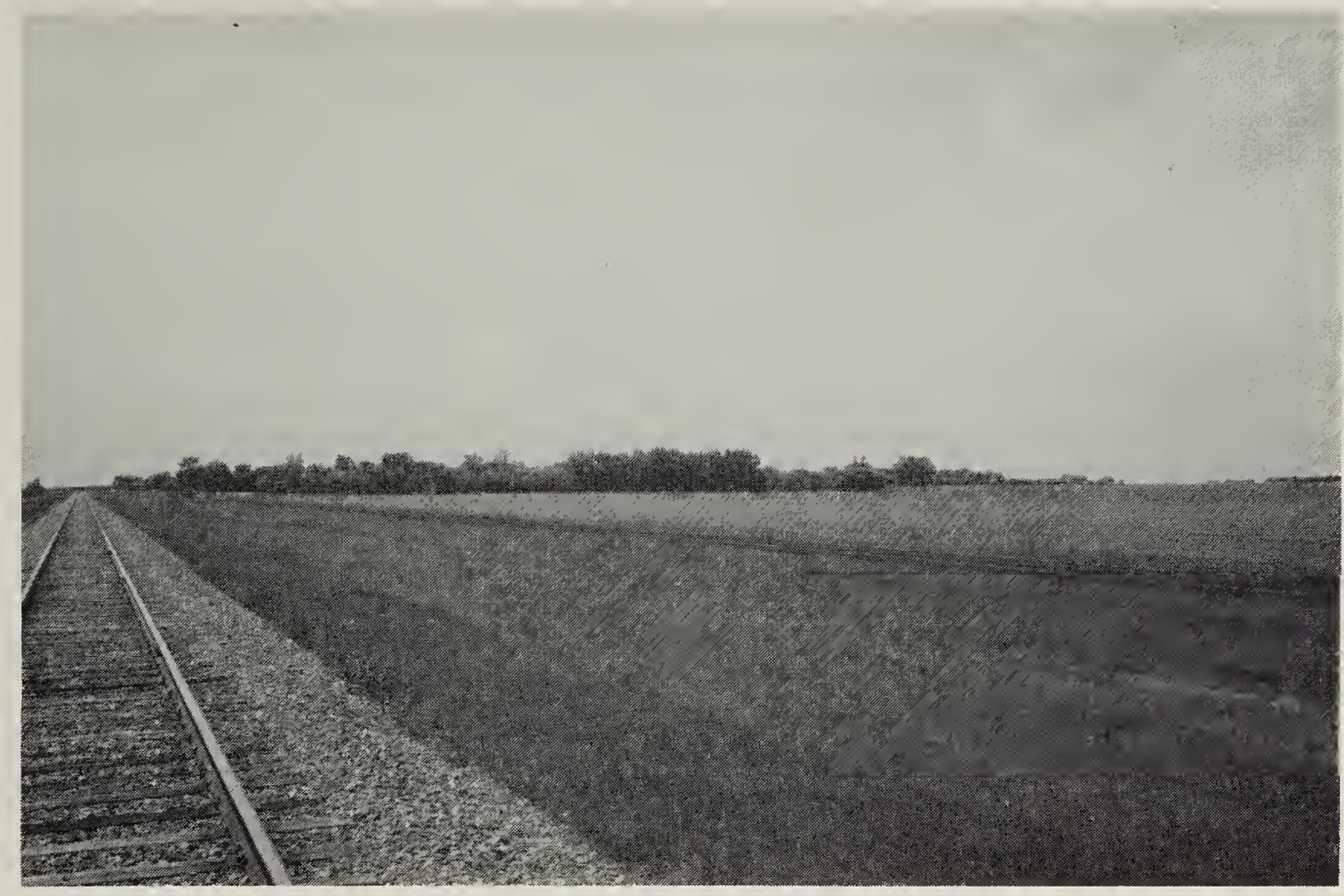

know that nesting can occur here. Although the Barn Owl generally is non-migratory and a permanent resident within its known range, banding records show that it is capable of travelling considerable distances. ${ }^{11,21}$ Hereafter, we will have to give more attention to reports of owls observed in barns; they just might be Barn Owls.

Acknowledgements This report would not have been possible without the cooperation of the entire McCaughan family: Réal and Kate, and James, Jesse, Joseph, Joleen and Julie. I am grateful to them for their hospitality and goodwill. Thanks are due their neighbours: Garry and Judy Stasynec, and son Brian; Ron and Connie Loeppky and family; Len and Ann Pedersen and family; Gerry and Shirley Sawchyn, Ed and Lynn Brown; Don Slobodzian and son Dustin; and others.

Special thanks are owed to James $R$. Duncan for identifying the prey remains and for joining me on some nighttime watches. Barn Owl specialist Len Soucy kindly provided a nest box design and considerable encouragement. Herbert W.R. Copland helped locate some records. Herb, on short notice, also supplied the band we put on the owl. Gordon G. Graham's comments on a draft were helpful; he also typed final drafts of the manuscript.

1. CARTWRIGHT, B.W. 1929. The Barn Owl (Tyto alba pratincola) in Manitoba. Auk 46:236.

2. COWAN, W.F. 1973. Ecology and life history of the raccoon (Procyon lotor hiatus) Nelson and Goldman in the northern part of its range. Ph.D. dissertation, Univ. North Dakota. Fargo, ND. $161 \mathrm{pp}$.

3. FOX, G.A. 1963. A possible recent record of the Barn Owl in Saskatchewan. Blue Jay 21:104.

4. GODFREY, W.E. 1986. The birds of Canada (revised edition). National Museums of Canada. Ottawa, ON. $595 \mathrm{pp}$.

5. GREEN, J.C. and R.B. Janssen. 1975. Minnesota birds, where, when, 


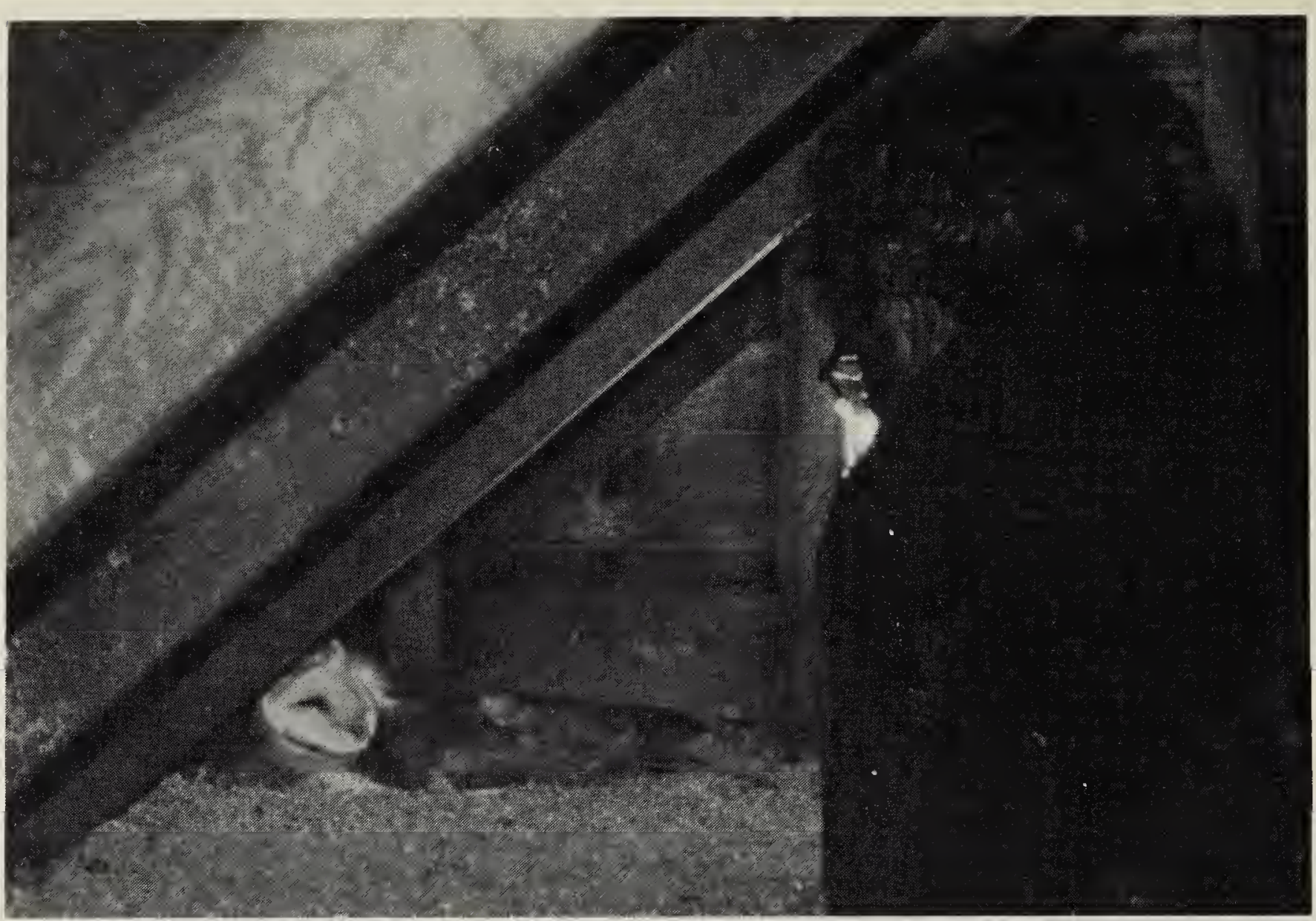

Réal McCaughan observing Barn Owl on nest, 9 June 1994.

R. Nero

and how many. Univ. Minn. Press, Minneapolis, MN. 217 pp.

6. HARRIS, W.C. 1988. Prairie Provinces Region. Am. Birds 42:93.

7. HENKE, R.J. and W.C. CRAWFORD. 1987. Common Barn-Owls from captive propagation found nesting in the wild. J. Raptor Res. 21:74.

8. HOLT, D.W., K. HICKS, and W.D. NORTON. 1992. First nest record for the Barn Owl in Montana. Prairie Nat. 24:121-122.

9. HOUSTON, C.S., R.D. CRAWFORD, and D.S. HOUSTON. Addled eggs in Great Horned Owl nests in Saskatchewan. In: Nero et al., editors. Biology \& conservation of northern forest ow!s: symposium proceedings. Gen. Tech. Rep. RM-142, USDA Forest Service, Ft. Collins, CO. 1987. Pp. 225-228.

10. JANSSEN, R.B. 1990. Barn Owl nests in Dakota County [MN]. The Loon 62:231.

11. JOHNSGARD, P.A. 1988. North American owls. Smithson. Inst. Press, Washington, DC. 295 pp.

12. MARTI, C.D. Barn Owl. In: Poole, A., P. Stettenheim, F. Gill, editors. Birds of North America No. 1. American Ornithologists' Union. 1991. 15 pp.

13. MIKKOLA, H. 1983. Owls of Europe. Buteo Books. Vermillion, SD. 397 pp.

14. MOSSOP, H. 1960. "Chickadee Notes" No. 299, Winnipeg Free Press, 7 October.

15. NERO, R.W. 1993. Probable Barn Owl records for Manitoba. Blue Jay 51:170-171.

16. SHORTT, A.H. 1960. "Wild Wings," Winnipeg Tribune, 21 November.

17. SMITH, H.C. 1967. Report on a Barn Owl at Regina. Blue Jay 25:22.

18. SMITH, W. 1967. The Barn Owl in Alberta. Blue Jay 25:187.

19. STEWART, R.R. 1975. Breeding birds of North Dakota. Tri-College Center for Environmental Studies. Fargo, ND. 295 pp.

20. TAYLOR, P. 1983. Wings along the Winnipeg. The birds of the Pinawa Lac du Bonnet region, Manitoba. Man. Nat. Soc. Eco Series No. 2. Winnipeg, MB. 216 pp.

21. VOOUS, K.H. 1988. Owls of the northern hemisphere. MIT Press, Cambridge, MA. 320 pp. 